\title{
History and Projects
}

\section{Carlo Cattaneo and Gaetano Salvemini: The Modernity of Their Federalism}

\author{
Erika Arban*
}

\begin{abstract}
Federalism and federal solutions in Italy have never enjoyed much popularity, although they have been discussed at different times as viable solutions for a country fragmented along socio-economic and linguistic lines. This mistrust can be partially explained by the fact that federalism has been often misunderstood and construed as synonymous with division and disintegration of the territory. In this specific context, Carlo Cattaneo and Gaetano Salvemini have emerged as two brilliant intellectuals and strenuous advocates of federalism for Italy, although they did so at different times and from different perspectives. Building upon primary and secondary sources, this article distills and compares the federal ideas of both thinkers, while at the same time emphasizing the modernity of their criticism and consequent solutions for Italy.
\end{abstract}

\author{
'Nella federazione \\ repubblicana saranno risolti \\ tutti i problemi: anche quelli \\ dell'Italia meridionale'. \\ G. Salvemini \\ 'Ogni Stato d'Italia deve \\ rimaner sourano e libero in sé \\ (...). Cosìne insegna la sapiente \\ America'. \\ C. Cattaneo
}

\section{Introduction}

It is well known that the institutional and constitutional history of Italy since the unification of 1861 has been defined by a strong centralist thrust, a legacy of the influential role played by the Napoleonic state model incarnated by the Kingdom of Piedmont, which lead to the unification process in the XIX century. The first decentralizing forces appeared only in the aftermath of World

* Research fellow, ARC Laureate Program in Comparative Constitutional Law, Melbourne Law School and Lecturer (part-time), University of Antwerp, Faculty of Law.

(C) Edizioni Scientifiche Italiane $\quad$ DOI 10.23815/2421-2156.ITALJ

ISSN 2421-2156 
War II, with the implementation of the 1948 Republican Constitution. This created a regional state, later strengthened by the constitutional reforms of the 2000s, which, at the time, seemed to be the prelude to a more radical federalization of Italy, a transformation that has not yet occurred. ${ }^{1}$ While federal ideas were not foreign to Italian political and intellectual circles and reforms in federal terms have been explored from time to time as a viable solution for a country deeply fragmented along socio-economic, political and linguistic lines, ${ }^{2}$ federal solutions have never enjoyed much popularity in Italy, with its halo of skepticism and lack of appreciation often surrounding federalism. Despite this reluctance in embracing the federal path, federal theory had its convinced advocates in Italy too. This essay particularly focuses on two brilliant and fascinating intellectuals who, although in rather different geographical and sociopolitical contexts, throughout their lives have convincingly praised federalism as the ideal solution for Italy and whose destinies are intimately intertwined. They are Carlo Cattaneo (1801-1869) and Gaetano Salvemini (1873-1957). Men of the utmost moral integrity and among the finest minds of their times, Cattaneo and Salvemini were prominent thinkers whose work has repeatedly triggered the intellectual curiosity of several researchers in Italy and elsewhere. Both very knowledgeable on a wide array of topics, Cattaneo and Salvemini were passionate advocates of federalism, who dedicated time, energy and resources to the study of how a federal solution might better serve the interests of Italy.

This contribution is thus devoted to their views on federalism and the points of convergence and divergence in their ways of conceiving and understanding federal theory and reforms, despite the different personal experiences and the profoundly different geographical and historical context and time in which they lived and worked. At least two reasons support the choice to examine federal thought of these two scholars. First, Salvemini's federalism was heavily influenced by Cattaneo's political writings and this emphasizes the intellectual bond linking the two thinkers. Second, many of the themes which they discussed and criticized in their writings (particularly the excessive centralization and bureaucracy of the Italian state, regionalism and the need for more extensive decentralization, etc) are still debated and discussed at high levels today; a testimony to the value and modernity of their ideas.

This article is structured as follows: in Part I, I shall revisit the federal thoughts of Carlo Cattaneo; Part II will be dedicated to Gaetano Salvemini and his federal

${ }^{1}$ It is not the purpose of this article to provide a detailed outline of the political events that led to unification, nor of the main features of the regional state model enshrined in the Italian Constitution before and after the constitutional reforms of the 2000s. Any reader who is interested in learning more about this can resort to the abundant literature existing on the topic, both in English and Italian.

2 In chronological terms, the most recent advocate of federalism at political level for Italy was Lega Nord, a political party that gained national prominence especially between the early 1990 and the early 2000s. 
ideas; in Part III, I shall seek to emphasize the similarities and differences between the two intellectuals on the specific topic of federalism.

\section{Carlo Cattaneo}

\section{Introduction and Biographical Notes}

The relationship between federalism and Italy is an old one; in fact, while in the years that led to unification, the Italian peninsula was nothing more than a fragmented territory composed of small states of various sorts and subject to foreign domination, 3 federal ideas had already started to sprout within certain élite circles based in Milan, thanks mainly to the federal vision of the brilliant Milanese intellectual Carlo Cattaneo. As a result, although the federal path was abandoned upon unification in 1861, federal solutions were certainly not ignored by the fathers of the Kingdom of Italy, even if the decision to opt for a centralized rather than a federal state was triggered by reasons that are still debated among scholars.

Carlo Cattaneo (1801-1869) was born in Milan at a time when the city was under French control. He received a law degree from the University of Pavia but never practiced law. More than a jurist, Cattaneo was an example of a true intellectual, regarded by many as one of the most versatile and multi-faceted thinkers of the Italian Risorgimento. He was a patriot and political scientist, captivated by all facets of knowledge. 4 At his death in 1869, he left an extensive scholarly heritage ranging over a wide array of subjects, including languages and literature, history, philosophy, economics, politics, law, infrastructure and chemistry, just to name a few. 5 Cattaneo was also the main editor of Il Politecrico, a review he founded in 1839, which comprised articles on several areas of knowledge. Despite his multi-faceted erudition, one of the subjects that most fascinated Cattaneo was federalism and the federal model ideally to recommend for an Italy undergoing unification. For this reason, I shall now explore in more detail Cattaneo's understanding of federalism, keeping in mind that this thinker

3 As famously stated, Italy 'was hardly more than a geographical expression'. See R. Putnam, Making Democracy Work. Civic Traditions in Modern Italy (Princeton, NJ: Princeton University Press, 1993), 121, quoting the Austrian statesman Klemens von Metternich. See also U. Amoretti, 'Italy Decentralizes' 13 Journal of Democracy, 129 (2002). In fact, in the aftermath of the Congress of Vienna of 1815, Italy was divided in eight states: the Kingdom of Piedmont and Sardinia (under the rule of the House of Savoy); Lombardy-Venetia (a territory/province of the Austrian Empire ruled by the Habsburg); the Dukedom of Modena and Reggio Emilia; the Dukedom of Parma and Piacenza; the Grand-Duchy of Tuscany; the Princedom of Lucca; the Papal State; the Kingdom of the Two Sicilies (ruled by the Bourbons).

4 C. Lacaita and F. Sabetti, 'Introduction', in C. Lacaita and F. Sabetti eds, Civilization and Democracy. The Salvemini Anthology of Cattaneo's Writings (Toronto, Buffalo and London: University of Toronto Press, 2006), 3.

5 F. Sabetti, The Search for Good Government. Understanding the Paradox of Italian Democracy (Montreal: McGill-Queen's University Press, 2000), 55. 
never condensed his federal vision into one or more specifically dedicated writings. Consequently, to distill Cattaneo's federal ideas, I consulted a number of primary and secondary sources, including two booklets containing a collection of writings directly written by Cattaneo on a number of different topics. ${ }^{6}$

\section{Federalism as a 'Theory of Freedom'}

Being a liberal thinker, freedom held the utmost importance for Cattaneo and this was a critical feature of his concept of federalism. In fact, in a letter written in 1851, he openly stated that federalism was the 'theory of freedom, the only possible theory of freedom'.7 He also argued that 'the only possible form of unity among free people is a federal covenant' as '(p)ower has to be limited'. ${ }^{8}$ Convinced that the federal state was the only political formula that allowed a perfect reconciliation between unity and freedom, Cattaneo argued that freedom implied a double limitation of political power, both at national and international levels.9 In fact, federalism (and by extension, freedom) meant decentralization among the component units of a federation, as well as the subordination of these federal states to a supranational (federal) entity. ${ }^{10}$ In other words, freedom conveyed the idea of enjoying, within the state, institutions that allowed autonomy and capacity to decide but also independence from foreign power. ${ }^{11}$ In this regard, Cattaneo argued that the 'supreme condition of freedom' was understood only by Switzerland and the United States, ${ }^{12}$ and that unity and freedom could be coupled only by following the Swiss or US model, thus showing how these two federal systems represented the ideal goal to which any country should

${ }^{6}$ In particular, I consulted the following: C. Cattaneo and N. Bobbio, Stati Uniti d'Italia. Scritti sul federalismo democratico with preface by Nadia Urbinati (Roma: Donzelli, 2010); C. Cattaneo, A nessun popolo più che allitaliano è concomitante la forma federale. Antologia degli scritti politico istituzionali with preface by Emilio R. Papa (Torino: Celid, 2002). All writings contained in these booklets are in Italian; consequently, the citations in the article are my translations. Similarly, all citations from secondary sources originally in Italian are my translations.

7 N. Bobbio, 'Introduzione', in C. Cattaneo and N. Bobbio, Stati Uniti d'Italia n 6 above, 19, quoting a letter sent to Lodovico Frapolli on 29 December 1851.

8 ibid 30, quoting a fragment of a letter sent by Carlo Cattaneo to a Sicilian friend.

9 Z. Ciuffoletti, Federalismo e regionalismo: da Cattaneo alla Lega (Roma-Bari: Laterza, 1994), 46-47; N. Bobbio, n 7 above, 18-19.

$10 \mathrm{Z}$. Ciuffoletti, $\mathrm{n} 9$ above, $46-47$.

11 ibid 41.

12 C. Cattaneo, 'L’Austria non volle essere una federazione di popoli se-reggenti', in Id, $A$ nessun popolo $\mathrm{n} 6$ above, 68. Incidentally, it may be noted that, at the time of Cattaneo, federal theory was simpler and more basic than today, as it had not yet reached the levels of complexity and sophistication that we presently know. Similarly, the United States and Switzerland (whose federal constitutions are dated 1787 and 1848 respectively) represented almost exclusively the only models of reference and it was to these two realities that most theorists looked for inspiration and ideas. Furthermore, Cattaneo's interest in the United States was due to the fact that it was seen as the most powerful and free federal state, while his specific focus on Switzerland was justified by his spending part of his life in Lugano, giving him first-hand knowledge of Swiss federalism. See N. Bobbio, n 7 above, 23 and 30. 
aspire. ${ }^{13}$

As I shall elaborate upon, Cattaneo's federalism partially emerged from the political and historical conflict existing at his time between Lombardy and the Kingdom of Piedmont, 14 although his federalism was free from any ethnic or geographical foundation. While he was aware of the existence of very diverse laws and traditions across Italy and Europe, for him federalism went beyond these differences and represented an ideal, the ultimate objective for which to yearn, as it embodied a 'political idea of freedom'.15 For Cattaneo, federalism could be defined as 'the law of the peoples', which should have its own place along with the 'law of the nation' and the 'law of humanity'. ${ }^{16}$

With specific regard to Italy, Cattaneo was against all forms of despotism and dictatorship and aspired to a republican (rather than a monarchical) form of government for the country undergoing the unification process, as monarchy could not be reconciled with people's liberties. ${ }^{17}$ In fact, he believed that the true nature of Italy was 'republican'. ${ }^{18}$ For this reason, he believed that the monarchical and centralized state that was being implemented on the Italian peninsula by the House of Savoy, rulers of the Kingdom of Piedmont (and strongly advocated, among others, by Giuseppe Mazzini) could only be authoritarian and despotic. Unity would suffocate autonomies, free initiative and freedom, while a plurality of political centers could protect and foster this freedom. ${ }^{19}$ Cattaneo used an effective metaphor to describe this:

'(w)hen huge wealth and power and honors are gathered in the hands of a central authority, it is too easy to build or acquire the majority within a single parliament. Freedom thus becomes only a name; everything is done as between masters and servants'. ${ }^{20}$

13 C. Cattaneo, 'Per la Sicilia', in C. Cattaneo and N. Bobbio, Stati Uniti d'Italia n 6 above, 61.

14 A. Lepre, Italia, Addio? Unità e disunità dal 186o a oggi (Milano: Mondadori, 1994), 25.

15 N. Urbinati, 'La federazione come politica di unità', in C. Cattaneo and N. Bobbio, Stati Uniti d'Italia n 6 above, I.

16 C. Cattaneo, 'Il diritto federale', in C. Cattaneo and N. Bobbio, Stati Uniti d'Italia n 6 above, 71 .

${ }_{17}$ N. Bobbio, $n 7$ above, 17. See also D.G. Rowley, 'Giuseppe Mazzini and the democratic logic of nationalism' 18 Nations and Nationalism, 50 (2012), where the author emphasizes how Mazzini, unlike Cattaneo, 'was no liberal' and 'opposed passionately the philosophy of individual rights upon which liberalism is based'. In fact, Mazzini's primary concern was 'the well-being of the community' and not of the individual.

18 C. Cattaneo, 'Per la Sicilia' n 13 above, 61.

$19 \mathrm{~N}$. Bobbio, $\mathrm{n} 7$ above, 21. While Cattaneo held Mazzini in high esteem, especially for his moral stature, he rejected the unitary idea which he was advocating, mainly for two reasons: first, he feared that, behind unitarism, there was an ambition towards dictatorship; second, he feared that the unitary model was just a pretext for compromises with the Papacy. See ibid 15 .

20 C. Cattaneo, 'L'ordinamento del regno', in C. Cattaneo and N. Bobbio, Stati Uniti d'Italia $\mathrm{n} 6$ above, 84. Cattaneo liked the use of metaphors to express his ideas and in other writings he explained federalism arguing that it was better to live as friends in ten houses, than live in 
Regarding Italy, Cattaneo always celebrated the importance of municipalities (comuni) as administrative and political entities within a larger federation, devoting some of his writing to this topic. ${ }^{21}$ Among other things, he invoked an Italian federal republic revolving around municipalities ${ }^{22}$ because, in historical terms, cities in Italy were (and still are) somewhat different to their equivalents in the far east or in the north. ${ }^{23}$ Cattaneo argued that comuni were the nation ${ }^{24}$ and that they were a 'spontaneous fact, as natural as the family'.25

Furthermore, Cattaneo did not favor a democracy based on universal suffrage ${ }^{26}$ and this represents an important difference from Salvemini, as will be explained later in the paper. Conceiving federalism as a theory of freedom, a federal model was enough to achieve the utmost democratic advancement as, for Cattaneo, the principle of democracy would not progress with universal suffrage but with the multiplication of self-government. ${ }^{27}$

While Cattaneo's federalism was rooted, at least in the beginning, in his Lombard origins, at the same time his federal vision was not geographically limited to his homeland but embraced Europe at large. His fixation was, in fact, the creation of the so-called 'United States of Italy' within the 'United States of Europe'. ${ }^{28}$ In this sense, he might be regarded as one of the forerunners of the dream of a European integration that would take shape only a century later. For him, European federalism was both a vector for long-standing peace among European states (as he famously stated, 'we will have true peace only with the United States of Europe') 29 but also for enhancing the economic wealth and

conflict in the same house' (C. Cattaneo, 'Sulla legge comunale e provinciale. Lettera seconda', in Id, A nessun popolo $\mathrm{n} 6$ above, 97) or that ' ( $\mathrm{t}$ )o be friends, everyone shall be the master of his own house' (C. Cattaneo, 'A Francesco Crispi, a Palermo', in Id, A nessun popolo $\mathrm{n} 6$ above, 110).

${ }^{21}$ See for example the collection of four letters under the title 'Sulla legge comunale e provinciale' contained in C. Cattaneo and N. Bobbio, Stati Uniti d'Italia n 6 above, 103, where he criticizes the administrative reform implemented in 1859, whereby the Kingdom of Piedmont extended to the Kingdom of Sardinia and the Lombard provinces their administrative system, extended also to all the territories later annexed.

${ }_{22}$ N. Bobbio, $n 7$ above, 31. See also C. Cattaneo, 'Il numero e la volontà', in C. Cattaneo and N. Bobbio, Stati Uniti d'Italia n 6 above, 65, where he argues that there should be no intermediary or subjection between municipalities and the central government.

${ }^{23}$ E.R. Papa, 'Prefazione', in C. Cattaneo, A nessun popolo $\mathrm{n} 6$ above, 13. 109.

${ }^{24}$ C. Cattaneo, 'Lettera prima', in C. Cattaneo and N. Bobbio, Stati Uniti d'Italia n 6 above,

25 ibid.

${ }^{26} \mathrm{~N}$. Bobbio, $\mathrm{n} 7$ above, 52.

27 ibid 53.

${ }^{28}$ C. Cattaneo, 'Avremo pace vera quando avremo li Stati Uniti d'Europa', in Id, A nessun popolo $\mathrm{n} 6$ above, 44; N. Bobbio, $\mathrm{n} 7$ above, 18, 21, 27 and 31.

29 C. Cattaneo, 'Avremo pace' n 28 above, 44; N. Bobbio, n 7 above, 27; Z. Ciuffoletti, n 9 above, 46-47. Incidentally, this idea of federalism as a mechanism to attain international peace was not new, as its origins can be traced back to the enlightenment, finding in Immanuel Kant and L'Abbé de St. Pierre the most prominent advocates. See for example D. Karmis and W.J. Norman, Theories of Federalism: A Reader (New York: Palgrave MacMillan, 2005), 53 and 54, where they refer to Kant's Towards Perpetual Peace of 1795 and L'Abbé de St. Pierre's Project 
well-being of the continent. In fact, he argued that the day that Europe could become similar to Switzerland or to America, the day when Europe would print on its forehead 'United States of Europe' not only would it be spared from wars, fires and gallows but it would also become wealthier. ${ }^{30}$

Before concluding this overview of Cattaneo's federal thinking, based on freedom, one more aspect is worth a brief mention, namely the relevance of family. In fact, Cattaneo intended family as the primordial and fundamental level of domestic organization. In his view, the human being was at the center of a series of 'concentric circles' departing from the family and expanding beyond

for Settling an Everlasting Peace in Europe of 1712. As for L'Abbé de St. Pierre, he propounded the constitution of a 'Commonwealth of Europe' formed by 19 states (the Empires of Germany and Russia; the kingdoms of France, Spain, England, Denmark, Portugal, Prussia, Naples, Sardinia; the Netherlands; Sweden; Poland; the Papal State and the ecclesiastical electorate; the Electorates of Bavaria and Palatine; Switzerland; the Republic of Venice). See L'Abbé de St. Pierre, 'Project for Settling an Everlasting Peace in Europe', in D. Karmis and W. Norman eds, Theories of Federalism (New York: Palgrave MacMillan, 2005), 69-70. As for Kant, he maintained that peace 'cannot be instituted or assured without a pact of nations among themselves (...) so there must be a league of a special kind, which can be called a pacific league (foedus pacificum), and what would distinguish it from a peace pact (pactum pacis) is that the latter seeks to end only one war whereas the former seeks to end all war forever'. See I. Kant, 'Towards Perpetual Peace', in D. Karmis and W. Norman eds, Theories of Federalism (New York: Palgrave MacMillan, 2005), 90. Kant also suggested that, in order to achieve perpetual peace, 'this idea of a federalism' should be extended to all states (ibid). In more recent times, Daniel Elazar has also embraced this idea that federalism represents an effective way to enhance and achieve peace within nations. See D. Elazar, Federalism and the Way to Peace (Kingston, ON: Institute of Intergovernmental Relations, Queen's University, 1994). In any event, the modernity and actuality of this view of federalism as vector for peace within Europe is buttressed by the fact that, in 2012, the European Union was awarded the Nobel Peace Prize for preserving peace across the continent for over sixty years.

$3^{\circ} \mathrm{C}$. Cattaneo, 'L'Austria non volle essere una federazione di popoli se-reggenti', in Id, $A$ nessun popolo $\mathrm{n} 6$ above, 68 . It is interesting to note that, while in the XVIII and XIX centuries times were not ready to carry out such an ambitious scheme of European unification, in the XX century the idea of a federal Europe regained force, particularly thanks to the work of Jacques Maritain in France and Altiero Spinelli in Italy. As co-founder, with Ernesto Rossi, of the Italian and European federal movements, Altiero Spinelli (1907-1986) drew inspiration from Cattaneo for his political ideas. See D. Karmis and W.J. Norman, n 29 above, 191. The Manifesto di Ventotene, written by Altiero Spinelli and Ernesto Rossi in 1941 and revised in 1944, is regarded as 'the most important theoretical and planned contribution expressed by Italian federalism since Cattaneo' (see Z. Ciuffoletti, n 9 above, VII). In the Manifesto, the two authors criticized the system of 'nation-states' that was, in their opinion, the principal cause of wars. See D. Karmis and W.J. Norman, $n 29$ above, 192. In fact, they alleged that ' $(t)$ he absolute sovereignty of national States has led to the desire of each of them to dominate, since each feels threatened by the strength of the others' (A. Spinelli and E. Rossi, 'The 1944 Ventotene Manifesto'. English excerpts available in D. Karmis and W.J. Norman, n 29 above, 199. The original (Italian) version of the document is available at https://tinyurl.com/yam34pug (last visited 25 November 2017)). Therefore, the first thing to do was 'the definite abolition of the division of Europe into national, sovereign States' (ibid 200). Similarly, the creation of the first European Communities in the 1950 and the 'functionalist' approach to EU economic integration embraced by Jean Monnet can be seen as the product of this strand of philosophical and political thinking dating back to L’Abbé de St. Pierre, Kant and Cattaneo. 
and further up to local communities, the State and the nation. ${ }^{31}$ This 'vision of a progressive polity', with a constant interplay among regions, cities and universities leading to 'a shared truth and a common good', certainly contrasted with the French unitary model much in vogue at the time. ${ }^{2}$

\section{Cattaneo's Federal Moments}

Cattaneo's federal vision was not fixed but continuously evolved to adjust to the historical events taking place in his time. The philosopher and historian, Norberto Bobbio (1909-2004), who extensively studied Cattaneo's life and work, identified three crucial phases of this intellectual evolution, as illustrated. 33

The first federal moment was in Cattaneo's younger days and ended with the insurrections of 1848.34 Because it was illegal in Lombardy freely to engage in political activism at that time, it is difficult fully to retrace Cattaneo's political ideas during this first phase. 35 However, he opposed the despotic and centralized regime of the Habsburgs, which, in his opinion, alienated citizens from institutions and prevented Lombardy to develop further. $3^{6}$ While the region was already enjoying relative well-being and prosperity, Cattaneo thought that Lombardy could continue to flourish only if the Austrian Empire would become a federation;37 indeed, a federal Austrian Empire would represent 'the first step towards the independence of Lombardy-Venetia'. 38 At least in theory, the Kingdom of Piedmont might represent for Lombardy a viable alternative to Austria but focused, as he was, on the well-being of Lombardy, Cattaneo believed that the Piedmontese Kingdom mirrored the French unitary model too closely,

${ }^{31}$ F. Sabetti, Civilization and Self-Government. The Political Thought of Carlo Cattaneo (Lanham, MD: Lexington Books, 2010), 93. In this sense, Cattaneo's federal theory recalls that of Johannes Althusius (1563-1638), the German Calvinist who is commonly regarded as the theoretical father of federalism, even if there is no evidence proving that Cattaneo knew Althusius. In any event, in his Politica Methodice Digesta of 1604, Althusius contended that the political organization should be structured in permanent associations such as families, collegia, cities, provinces, and then the state and the republic; moreover, through these associations, citizens could function, be represented and preserve their freedoms.

${ }^{32} \mathrm{M}$. Thom, 'City and language in the thought of Carlo Cattaneo' 5 Journal of Modern Italian Studies, 7 (2000).

33 N. Bobbio, $n 7$ above, 25.

34 ibid. The Lombard insurrection of 1848 and the notorious 'five days of Milan' erupted as a rebellion against Austrian control over the territory.

35 G. Salvemini, 'Cattaneo's Life and Work', in C. Lacaita and F. Sabetti eds, Civilization and Democracy. The Salvemini Anthology of Cattaneo's Writings (Toronto, Buffalo and London: University of Toronto Press, 2006), 56.

$3^{6}$ E.R. Papa, n 23 above, 14. Cattaneo used to refer to Vienna (the capital of the Empire) as the 'nest of slavery'. See C. Cattaneo, 'Programma del Cisalpino', in C. Cattaneo and N. Bobbio, Stati Uniti d'Italia n 6 above, 57; in another document, Cattaneo alleged that 'any order that Austria can establish in Italy, is anarchy'. C. Cattaneo, 'Avremo pace' n 28 above, 35; G. Salvemini, 'Cattaneo's Life' n 35 above, 56-57.

37 N. Bobbio, $n 7$ above, 26.

38 ibid 21. 
so in the end it was as despotic as were the Austrians. ${ }^{39}$ Furthermore, it was heavily bureaucratized and had an intrusive clergy, so he believed that these facts would not help to advance Lombardy's socio-economic development. $4^{\circ}$ At this stage, federalism was thus broadly construed as an ideology to apply to European politics at large, ${ }^{41}$ particularly with regard to the Austrian Empire, without yet considering a federal solution for Italy.

With the failure of the 1848 uprisings and the return of Lombardy under direct Austrian control, Cattaneo's federalism entered a second phase, which would last until about 1860.42 At this stage, Cattaneo's attention shifted towards Italy and the creation of an Italian federation composed of all the formerly independent entities. $43 \mathrm{~A}$ federal scheme was viewed as the best way to achieve the Italian unification. Because, as noted, the two only models of federation existing at the time were the United States and Switzerland,44 Cattaneo looked at these two schemes 45 and argued that

(e)ach Italian State shall remain free and sovereign (...) each population shall be at home, under the protection and supervision of the others. This is what America teaches us'. ${ }^{46}$

Cattaneo, however, was not only interested in pursuing political federalism, as he also promoted some sort of administrative federalism for Italy; in fact, he was convinced that excessive administrative centralization would lead to overwhelming bureaucracy. 47 In a system that was too centralized, Cattaneo contended that it would be very difficult for a Piedmontese or for one from Lombardy to understand how to resolve certain issues arising in Sicily or Sardinia, and wondered how a parliament would find the time to discuss all the questions that administrative and legislative centralization had taken away from the periphery to direct to the center. Only the creation of the highest number of local autonomies and locally elected public servants, while reserving to the national parliament only issues of national concern, could effectively impede the formation of a bureaucratic caste. $4^{8}$ In this regard, he argued that

'a parliament assembled in London will never satisfy America; a parliament assembled in Paris will never satisfy Geneva; laws discussed in

39 M. Thom, n 32 above, 2; G. Salvemini, 'Cattaneo's Life' n 35 above, 57.

40 E.R. Papa, n 23 above, 14; G. Salvemini, 'Cattaneo's Life' n 35 above, 57.

${ }^{41} \mathrm{~N}$. Bobbio, $\mathrm{n} 7$ above, 25.

42 G. Salvemini, 'Cattaneo's Life' n 35 above, 6o; N. Bobbio, n 7 above, 27.

43 N. Bobbio, $n 7$ above, 27.

44 The Canadian federation is dated 1867, the German federation 1871 and the Australian one 1901.

45 F. Sabetti, Civilization n 31 above, 131.

46 C. Cattaneo, 'Avremo pace' n 28 above, 37.

47 G. Salvemini, 'Cattaneo’s Life’ n 35 above, 68.

48 ibid 69. 
Naples will not resurrect (...) Sicily and a Piedmontese majority (...) could not expect to have its provisions tolerable in Venice or Milan'.49

The third moment of Cattaneo's federal thinking begins after the unification of Italy under Piedmont, with the extension to the whole territory of the laws and bureaucratic apparatus of the Kingdom (the so-called Piedmontization of Italy) and the dismissal of all federal solutions. $5^{\circ}$ The Milanese deeply abhorred the Piedmontization and he harshly criticized it in a letter sent in 1859 to a friend, in which he argued that it would only generate confusion and disagreement to extend a whole body of mostly flawed and old laws from one state to the other, and to extend public officers inexperienced of the people and the local traditions. ${ }^{51}$ Cattaneo also contended that

'among all our peoples there is an awareness that the present system, conceived for one state and not for a plurality of united states, is not sufficient to satisfy their needs'. 52

In any event, with the failure of the federal project, from 1860 until his death, Cattaneo focused exclusively on the idea of devolution and decentralization. 53 This meant that, while still believing that federalism was the only possible way to unify Italy, he acknowledged the failure of this idea and worked towards some form of legislative and administrative autonomy of local self-entities. 54

\section{The Failure of Cattaneo's Federal Ideas}

As noted, when Italy was unified in 1861, the federal model advocated by Cattaneo was abandoned to embrace the centralized paradigm of Napoleonic traditions. For this reason, many scholars have tried to identify the reasons behind the defeat of Cattaneo's federal project for Italy, although this failure seems to have been the result of a concatenation of different causes.

In the first place, at the time of Cattaneo, there was widespread skepticism towards federalism and federal solutions, seen as synonymous with disaggregation and weakening of the unity of the Italian territory that was undergoing unification. In fact, Giuseppe Mazzini and other patriots strongly believed that a federal structure for Italy would lead to civil wars or to conquest through external wars and this was in sharp contrast with Cattaneo's philosophy.55 Because of this conviction, Cattaneo and federalists in general were often accused of

49 C. Cattaneo, 'Il diritto federale' n 16 above, 71.

5o See M. Thom, n 32 above, 2; G. Salvemini, 'Cattaneo's Life' n 35 above, 63.

${ }^{1} \mathrm{~N}$. Bobbio, $\mathrm{n} 7$ above, 41, citing an excerpt of a Lettera ad un amico sent by Cattaneo on 12 July 1859.

$5^{2}$ C. Cattaneo, 'Contro l'ordinamento del Regno', in Id, A nessun popolo n 6 above, 83.

$53 \mathrm{~N}$. Bobbio, $\mathrm{n} 7$ above, 40.

54 N. Urbinati, $\mathrm{n} 15$ above, XXII.

55 Z. Ciuffoletti, n 9 above, 45. 
'municipalism', as the opponents of federal ideas (who were the majority at the time) construed federalism as the equivalent of destruction of the nation and antechamber of civil war..$^{6}$ Cattaneo often complained that in Italy there was a lack of true understanding of federalism and since it was frequently opposed to unity, it was construed as a principle of isolation and separation and as such, ran counter to the ideals of Risorgimento.57 Cattaneo tried many times to uphold his federal ideas as being not against unity (as many believed) but against a 'fusion' of territories, as fusion meant for him 'confusion' and confusion 'only generates weakness and mistakes'. ${ }^{8}$ In fact, he believed that a covenant among free people (ie a federal state) was the solution leading to unity and harmony, while fusion would lead only to divorce and hatred.59 Cattaneo also explained that the co-ordination of the two legislative orders (that of the union and those of the individual constituting entities), would not lead to dissolution or disagreement; rather, it was the precondition for friendship and agreement ${ }^{60}$ and that the multiplicity of legislative councils and administrative powers were the 'necessary conditions to freedom'.61 Furthermore, at the time, there was some confusion in the language adopted; in fact, the terms 'federation' and 'confederation' were used as synonyms, when, in reality, they refer to two very distinct things. ${ }^{62}$ All this notwithstanding, federalism continued to be construed with great skepticism by the majority, a negative perception that still exists today.

Since Cattaneo was very critical of the creation of a centralized state, his federal vision was considered inappropriate and dangerous, especially in the light of the efforts that initially the Kingdom of Piedmont and later the Kingdom of Italy were making to unify the territory. ${ }^{6} 3$ Hence, Cattaneo was quickly labeled as the opponent of the unitary state and the same concept of federalism assumed

56 ibid 45. See also D. Hine, 'Federalism, Regionalism and the Unitary State: Contemporary Regional Pressures in Historical Perspective', in C. Levy ed, Italian Regionalism. History, Identity and Politics (Oxford and Washington, DC: Berg, 1996), 110; D.G. Rowley, n 17 above, 50, where the author explains how Mazzini 'hoped for a unified and independent Italy'.

57 N. Bobbio, $n 7$ above, 50. As further explained below, Salvemini lamented that the federal idea was 'perfectly unknown' in Italy even by those who were supposed to have a good knowledge of it (like constitutional law and administrative law scholars). See G. Salvemini, 'L'autonomia comunale e il congresso di Parma', in Id, Scritti sulla Questione Meridionale (1896-1955) (Torino: Einaudi, 1955), 135 .

$5^{8}$ N. Bobbio, $\mathrm{n} 7$ above, 27.

59 ibid 28, quoting a letter that Cattaneo wrote to Giuseppe Ferrari.

60 C. Cattaneo, 'L'ordinamento del regno' n 20 above, 83.

61 ibid 84.

${ }^{62} \mathrm{~N}$. Bobbio, $\mathrm{n} 7$ above, 50 . Without going into the technicalities of the differences between a federation and a confederation, here suffices to say that, in broad terms, in a confederation, sovereign and independent states join together on the basis of an international treaty (and is therefore a model belonging to international law), where decisions are taken by unanimous consent of the participating members and there is usually a provision allowing for the secession of one or more constituent units. The first European Communities, set up in the 1950s, were usually seen as examples of confederal arrangements.

63 ibid 50. 
this negative connotation of anti-unitary and anti-state principle, one that perpetuated a feudal system of state-nations that the Risorgimento was trying to eliminate. ${ }^{64}$ As noted, the supporters of the unitary and centralized state believed that the federal model advocated for Italy by Cattaneo would restore the 'system of the old small republics'.65 In fact, the patriot, Giuseppe Mazzini, was against this federal scheme, since he believed that by giving predominance to local autonomies, Italy would move back to the small republics of the middle ages. ${ }^{66}$ Furthermore, opponents of the federal solution for Italy believed that a federal state would be appropriate only for pluri-national states and 'the unity of the Italian nation would imply the unity of the state'. 67

Another reason that helps explain the failure of Cattaneo's federal project for Italy was the way in which the Italian unification process was carried out. The urge to complete national unification as soon as possible and the need quickly to take advantage of the favorable international situation pushed Cavour to proceed without delay towards the annexation of the various territories of the peninsula (a process dubbed the Piedmontization of Italy, as noted above). ${ }^{68}$ In other words, the ex novo creation of a federal state was perceived as an endeavor that required too much time and energy as well as huge financial and institutional effort (necessary also to train public servants appropriately) and since there was not enough time for that, all the various territories in the peninsula were quickly annexed by the Kingdom of Piedmont, later renamed Kingdom of Italy. 69

Moreover, scholars point out that Cattaneo's federalism failed also because it lacked an active organization and structure, as it enjoyed the support of intellectuals but was generally neglected by politicians and men of action ${ }^{70}$ and it was never elaborated into a theory of federalism that could be used by jurists or politicians. ${ }^{71}$ Cattaneo himself argued that the very essence of federalism was misunderstood because of a lack of propaganda, 'there is no religion without a preacher' ${ }^{72}$ Furthermore, Cattaneo had a very negative idea of politics, seeing it as 'hatred' and 'perpetual fight' 73 and deliberately chose to keep himself far from power and political activism,74 convinced that he could better serve his country

64 ibid.

65 C. Cattaneo, 'Il diritto federale' $\mathrm{n} 16$ above, 71. In Italian, the expression used by Cattaneo was 'sistema delle vecchie repubblichette', the latter term being a diminutive and a pejorative of the word 'repubbliche'.

${ }^{66} \mathrm{~N}$. Bobbio, $\mathrm{n} 7$ above, 137, fn 14.

${ }_{7} 7 \mathrm{ibid}$ 32. In this sense, we can detect the confusion existing between the meaning of federation and that of confederation.

68 Z. Ciuffoletti, n 9 above, 49-50.

69 D. Ziblatt, 'Rethinking the Origins of Federalism: Puzzle, Theory, and Evidence from Nineteenth-Century Europe' 57 World Politics, 86 (2004).

${ }^{70} \mathrm{~N}$. Bobbio, $\mathrm{n} 7$ above, 49 .

${ }^{71}$ ibid 30.

72 ibid 50, citing an excerpt of Cattaneo's Lettera to Cernuschi of 1861.

73 ibid 43, citing an excerpt of a letter that Cattaneo sent to his wife in 1848 .

74 Although it is fair to say that Cattaneo was not completely distanced from political activism, 
through his intellectual and critical research. 75 Certainly, this did not help the federal cause for Italy, as there was no one ready to support it politically. Thus, Cattaneo's lack of political activism contributed to making Italian federalism an idea too abstract to be concretely realized. ${ }^{6}$

Finally, it should be noted that, while a convinced advocate of it, Cattaneo's federal project was too indefinite and theoretical to be realized in practice. In fact, Cattaneo did not leave behind any written work dealing with specific 'federal' issues, such as separation of powers or jurisdictional conflict, which would have clearly condensed his federal vision for Italy into one single document.77 As his ideas on federalism were scattered among many writings, the fathers of unification could not rely on any written document clearly detailing how federal Italy should be designed.

In any event, besides the defeat of Cattaneo's federalism as a project for Italy, federal ideas at his time found obstacles throughout Europe, because of the presence of national states of ancient tradition, multinational empires and strong social tensions within each state. Advocates of federalism were regarded as conspirators in a model that was against the idea of nation and therefore defenders of feudal particularism and of aristocratic privileges, thus working against the idea of 'nation'.78

\section{Gaetano Salvemini}

\section{Biographical Notes}

as he participated in the events surrounding the 'five days of Milan' in 1848 and later became a member (much against his will, as Norberto Bobbio contends) of the newly-formed Italian Parliament after the unification of Italy. See N. Bobbio, $\mathrm{n} 7$ above, 37 and E.R. Papa, $\mathrm{n} 23$ above, 16.

75 N. Urbinati, $n 15$ above, XIX.

${ }^{76} \mathrm{~N}$. Bobbio, $\mathrm{n} 7$ above, 49-50.

77 E.R. Papa, $n 23$ above, 13.

$78 \mathrm{Z}$. Ciuffoletti, $\mathrm{n} 9$ above, 10. While still quite strong in Italy, this negative perception of federalism has progressively faded in Europe (federal states were implemented in Germany, Austria and most recently, Belgium) but they have never fully disappeared and can be seen as the major obstacles to the creation of a fully-fledged federal Europe. Incidentally, besides Cattaneo's federal writings, it is worth mentioning a question that is often raised, particularly in north America as to whether or not the outbreak of the US civil war between 1861 and 1865 (practically the same time-frame as the Italian unification) may have played any deterrent role in the implementation of a federal model in the peninsula. This is a legitimate concern, especially because of the continuous cross-references to federalism as a vector of disruption of the unity of the state and bearer of internal conflicts. However, I do not believe that the particular unfolding of events in America played any major role in the (mis)fortunes of federalism in Italy. As mentioned, after centuries of foreign conquest and division into small entities, the Risorgimento was the time when Italians began dreaming of a strong and unified state, in the tradition of other European sovereign state systems. Anything that would imply an internal division into smaller units (like a federation or a confederation) was seen by many as a return to the past, where foreign domination and local conflicts were the rule. Cattaneo's ideas were probably too sophisticated to be fully grasped at the time. 
Until the 1890 s the thrust towards a broader decentralization was essentially coming from the north of the country, mainly from Lombardy which, along with Veneto, was among the most industrialized geographic areas and whose needs and priorities were different than those in the south, still anchored to a quasi-medieval and rural economy. Towards the end of the XIX century, decentralization became a driving force in the discussion of the questione meridionale (the southern question).79 In fact, the idea that the economic and social backwardness of the south was caused by the strong centralism of the state, which implied the exploitation of the poorer south by the richer north, was becoming more and more popular, to the point that many began to consider the forced unification of 1861 under the Piedmontese to be a grave error for Italy. ${ }^{80}$ It was in this context that Salvemini emerged as one of the most representative southern federalists.

Inspired by the work and ideas of Cattaneo, the historian and political writer of modest origins, Gaetano Salvemini, was born in 1873 in Molfetta, in the Apulia Region. ${ }^{81}$ He taught extensively in high schools and was then appointed professor of medieval and modern history at the University of Messina (1901-1910), before moving to Pisa (1910-1916) and Firenze (1925) to continue with his academic career. Between 1919 and 1921, Salvemini was also actively engaged at a political level, being a member of the Italian Parliament. ${ }^{82}$ He collaborated with reviews such as 'Critica Sociale, 'Avanti!' and 'Voce' and was the founder and director of 'L'Unità'.83 In 1925, he left Italy for France, England (where he lectured on Italian foreign policy at King's College, London) and eventually the United States, where he taught at Harvard University from 1934 to 1946. He would come back to Italy in 1947 and he resumed his teaching job at the University of Florence. He died in Sorrento, near Naples, in $1957 .{ }^{84}$

To retrace Salvemini's federal thinking, reference is primarily to the text Scritti sulla Questione Meridionale (1896-1955) (hereinafter, Scritt), ${ }^{85}$ a collection

79 Z. Ciuffoletti, n 9 above, 81. See also J.A. Davis, 'Changing Perspectives on Italy's 'Southern Problem" in C. Levy ed, Italian Regionalism. History, Identity and Politics (Oxford \& Washington, DC: Berg, 1996), 53.

80 Z. Ciuffoletti, n 9 above, $83-84$.

${ }^{81}$ C. Lacaita and F. Sabetti, n 4 above, 29.

82 G. Salvemini, 'Prefazione', in Id, Scritti sulla Questione Meridionale n 57 above, XXX.

83 It is important to point out that 'L'Unità' founded and directed by Gaetano Salvemini was a review in which he mainly described his federal ideas and should not be confused with the newspaper 'L'Unità', founded in 1924 by Antonio Gramsci, as the official newspaper of the Italian Communist Party.

84 For more detailed bibliographical notes on Gaetano Salvemini, see Enciclopedia Treccani, available at https://tinyurl.com/y9zg43h4 (last visited 25 November 2017); see also C. Lacaita and F. Sabetti, n 4 above, 46-48; F. Barbagallo, 'Gaetano Salvemini e il problema del Mezzogiorno' Studi Storici, 636 and 639 (2007).

85 G. Salvemini, Scritti sulla Questione Meridionale n 57 above. In English, the title might be presented as Writings on the Southern Question. As for Cattaneo, in this case all translations from Italian to English are mine. 
of writings from the first half of the twenty century 86 in which Salvemini engaged with great clarity of mind in the study and analysis of a wide array of themes. With the south of Italy (the Mezzogiormo) as its main focus, even if some of these writings are examples of his political activism, inter alia, he talked about the illiteracy of the masses, the harsh lives and working conditions of the southern working-class but also criticized the extreme parochialism of this territory. Specifically, Salvemini celebrated universal suffrage as the only solution to emancipate the people living in this region. From the Scritti, Salvemini emerged as a profound and accurate expert and observer of the south of Italy, carefully painting its social fabric and its residents. While the Scritti are not a work on federal theory, federalism is nonetheless celebrated by Salvemini as an ideal solution for Italy and especially for the north. Consequently, I will not analyze all the writings contained in the text, but only those where the scholar considers a federal Italy.

\section{Salvemini's Federal Thinking as Shown in the Scritti}

\section{a) The Centralized State Model and Excessive Bureaucracy}

As did Cattaneo a few decades earlier, Salvemini criticized the centralized state as proposed in 1861, especially from his southern perspective, as a 'carefree and greedy devourer of national riches' whose only concern, over the decades since unification, was to 'fill up the always empty coffers of the central government' with new taxes, without leaving any possibility for municipalities to levy their own taxes. ${ }^{87}$ In this regard, Salvemini acknowledged that the unification of Italy brought some advantages to the south but at the same time he believed that 'the damages exceeded the benefits'. 88 Indeed, he explained the backwardness of the south (as opposed to the wealth of the north), arguing that it was the product of the 'disastrous conditions created in the south by the financial and administrative centralization of monarchic Italy'. ${ }^{89}$ Even corruption, so pervasive in that part of the country, was for him a 'necessary consequence of centralism'.90 Similarly, Salvemini harshly attacked the excessive bureaucratization of Italy, construing it as one of the Italian evils. In his opinion, Italy was

86 The Scritti sulla Questione Meridionale also help in retracing the evolution of Salvemini's ideas over the time. In fact, as it often happens for many thinkers and intellectuals Salvemini's thinking was not static and firmly anchored but evolved and changed in time. As he also pointed out, 'in half a century one does not merely live, one also learns'. See G. Salvemini, Prefazione $\mathrm{n} 82$ above, XXXVI.

87 G. Salvemini, 'Per un congresso nazionale dei consiglieri comunali democratici', in Id, Scritti sulla Questione Meridionale n 57 above 65. above, 62 .

88 G. Salvemini, 'Risposta ad un'inchiesta', in Id, Scritti sulla Questione Meridionale n 57

89 ibid 61. above, 116.

90 G. Salvemini, 'La Questione di Napoli', in Id, Scritti sulla Questione Meridionale n 57 
governed by a 'mammoth, lazy and inefficient bureaucracy' that was 'attracting to Rome millions of files' that nobody would care for and therefore were left dormant. 91

The problem with such an excessive administrative centralization was that the administrative officials would not be in a position effectively to monitor all the files coming from the periphery to the center. ${ }^{2}$ However, for Salvemini, an excessive administrative centralization and bureaucracy would not simply slow down and compromise effectiveness but would also cause administrative corruption. In fact, he believed that 'administrative corruption was a necessary consequence of centralization'.93

The solution to this state of affairs would therefore be to break up the administrative unity of the State' and create a federal model (which would be different to a mere 'decentralization') for Italy, in which the central government would have no influence whatsoever on entities of local self-government.94 I shall revert to Salvemini's federal project later in the article.

\section{b) The Southern Question}

Salvemini's federalism is intimately intertwined with and thus cannot be separated from the southern question. Consequently, before distilling his federal thinking, it is important first to explain the questione meridionale. Being a southern intellectual and a first-hand expert on the problems of the Mezzogiorno, Salvemini had always been very concerned with the backwardness and underdevelopment of the south and struggled to explain the origins of this socio-economic cleavage with the north, before suggesting federalism as a means to overcome this. In this regard, he argued that among the reasons behind this backwardness at the time of unification in 1861, was that the south was already much more underdeveloped than the north and the ensuing financial and administrative centralization of monarchical Italy was disastrous for the south. 95

In emphasizing this deep socio-economic, political, intellectual and moral cleavage between the north and the south, ${ }^{6}$ Salvemini identified what he believed to be the three 'illnesses' suffered by the south. The first 'illness', not unique to the south but also shared by the north, was a state that was 'centralizing, devourer, destructive',97 as already indicated. The second 'illness' was represented by the economic oppression of the south caused by the north, further emphasizing

${ }^{91}$ G. Salvemini, 'Prefazione’ n 82 above, XXXI.

92 G. Salvemini, 'La Questione di Napoli’ n 90 above, 109-110.

93 ibid 116.

94 ibid 116 and 120.

95 G. Salvemini, 'Risposta ad un'inchiesta' n 88 above, 61. In this regard, Salvemini further explains that the south was struggling also against local conservative forces (ibid).

96 ibid 60.

97 G. Salvemini, 'La Questione Meridionale', in Id, Scritti sulla Questione Meridionale n 57 above, 32 and 36 . 
how the unification campaign under Giuseppe Garibaldi was seen by northern conformists as a true 'act of conquest' of the south ${ }^{98}$. In this regard, he argued that the fight between the industrialized north and the Mezzogiorno would never end unless and until the unitary state would be replaced by a federation. 99 In analyzing the data contained in a work published by Francesco Saverio Nitti in $1900,{ }^{100}$ Salvemini argued that

'the privileged condition of the north (...) has caused, over these past forty years, a continuous outflow of wealth from the south to the north'101 (thus allowing the north to) 'magnificently develop its own resources and create a splendid industrial production, while the south has remained underdeveloped and miserable'.102

In conclusion, for Salvemini, 'the wealth of the north is produced by the poverty of the south'.103 The third and last 'illness' was the semi-feudal social fabric of the south, a problem that was very old (compared to the previous two, which were the product of unification) and unique to the Mezzogiorno, seen as an anachronism compared to the bourgeois structure existing in the north, which prevented people to develop their self-government skills. ${ }^{104}$ However, for Salvemini, these 'illnesses' would never be cured by the central state, as the solution could only come from a movement originating locally. ${ }^{105}$

Salvemini also drew attention to the profound resentment existing between the north and the south, with the consequence that the southerners loathed the northerners and the northerners detested the southerners, this state of things being the 'product of forty years of unification'. 106

\section{c) The Federal Solution}

By his own admission, Salvemini's federalism was deeply influenced by Carlo Cattaneo, ${ }^{107}$ whose writings were found by Salvemini in 1898-1899 (along with those of other Lombard political thinkers of the XVIII and XIX centuries)

98 ibid 33 and 36.

99 ibid 34.

100 The title of the work is 'Nord e Sud. Prime linee di una inchiesta sulla ripartizione territoriale delle entrate e delle spese dello Stato in Italia'. In English, the title could be rendered as 'North and South. First results of a survey on the territorial allocation of State revenues and expenses in Italy'.

${ }^{101}$ G. Salvemini, 'La Questione Meridionale e il Federalismo', in Id, Scritti sulla Questione Meridionale $n 57$ above, 76.

102 ibid 78 .

103 ibid 79.

104 G. Salvemini, 'La Questione Meridionale’ n 97 above, 34 and 36.

105 ibid 37-38.

106 G. Salvemini, 'La Questione Meridionale e il Federalismo’ n 101 above, 68-69.

107 G. Salvemini, 'Prefazione' n 82 above, XVI. 
when he was a professor of history in a high school in Lodi. ${ }^{108}$ The admiration that Salvemini had for the work and thinking of Carlo Cattaneo is confirmed by the fact that in 1922 he published an anthology of Cattaneo's writings. ${ }^{109}$

From his southern perspective, for Salvemini federalism was, first and foremost, the solution for all southern evils (or 'illnesses', as described above), ${ }^{110}$ an idea that 'was more popular than one might hope'. ${ }^{111}$ Salvemini believed that a renaissance of the south of Italy would be possible only through the dismantling of a centralized public administration, as he recognized that federalism had the merit of favoring the education of rural masses and the growth of political awareness among southern farmers. ${ }^{112}$ Consequently, he advocated the creation of a federal Italy in which the south would become 'the owner of all its resources', with a central government excluded from all influence on local self-governments and citizens finally responsible for themselves. ${ }^{113}$ Furthermore, Salvemini believed that, while federalism would probably not eliminate all forms of corruption, it would certainly reduce it to the minimum, for the simple reason that each public official would enjoy limited spheres of responsibility. ${ }^{114}$

Salvemini also believed that only a federal solution would help in eliminating 'all artificial financial and economic unbalance among Italian regions'115 and in resolving all issues of 'distributive justice' between the north and the south.116 He thought that a federal scheme would allow for the creation of solidarity-based relationships among the various regions, inspired by a sense of justice, which was guaranteed by the detachment of federal institutions from local issues.

A drastic reform of Italian politics would thus be needed to implement the following: ${ }^{117}$ (a) a federalist structure and; (b) universal suffrage, so that the rural and middle classes alike might take part in public life. ${ }^{118}$ Salvemini was strongly convinced that federalism and universal suffrage had the power to educate the masses because, in a federal system, citizens would be educated to public life, counting upon their own initiative and not on a distant authority. ${ }^{119}$ Salvemini

\footnotetext{
108 ibid.

109 C. Lacaita and F. Sabetti, n 4 above, 5-6 and 29.

$110 \mathrm{G}$. Salvemini, 'Prefazione' n 82 above, XVI.

${ }^{111}$ G. Salvemini, 'La Questione Meridionale e il Federalismo' n 101 above, 1.

${ }^{112}$ F. Barbagallo, $\mathrm{n} 84$ above, 640.

${ }^{113}$ G. Salvemini, 'La Questione di Napoli’ n 90 above, 116.

114 ibid 122.

115 G. Salvemini, 'La Questione Meridionale e il Federalismo' n 101 above, 86; see also Z. Ciuffoletti, $n$ above, 87-88.

116 G. Salvemini, 'Federalismo, Regionalismo e Autonomismo', in Id, Scritti sulla Questione Meridionale $\mathrm{n} 57$ above, 597.

117 G. Salvemini, 'La Questione Meridionale e il Federalismo' n 101 above, 86; see also Z. Ciuffoletti, $\mathrm{n} 9$ above, 36 .

118 G. Salvemini, 'Nord e Sud nel partito socialista italiano', in Id, Scritti sulla Questione Meridionale n 57 above, 153; Id, 'Il suffragio universale e le riforme', ibid, 232; Id, 'Socialisti e suffragio universale', ibid, 309; Id, 'Che fare?,' ibid, 350; Id, 'Un pranzo alle otto di mattina', ibid, 400.

119 G. Salvemini, 'La Questione di Napoli’ n 90 above, 119.
} 
also noted that, in a federal system, sovereignty would be exercised by the people and people would be moved by their own daily interests to take charge of their local realities. This daily exercise of sovereignty allowed for educating the masses to politics and local administration. Conversely, in a unitary state, people would just vote for a certain number of representatives who would be unknown to them and who, eventually, would enjoy immense power. To be able to vote well, it was considered necessary to have the finest education, something that was a prerogative of only a minority. ${ }^{120}$

As for the federal solution, it would be very simple. A radical administrative decentralization, with municipalities vested with powers on matters such as road systems and ports, hygiene, water, justice, education, the army, public policy and finances and regional and municipal governments, while the central government would oversee all matters of general or national interest, such as foreign policy, customs, monetary policy, as well as civil, criminal and commercial legislation. ${ }^{121}$ Furthermore, regions and municipalities should be in position to levy their own taxes and keep them locally, except for the sums that would be funneled to the center for national concerns. In this way, each municipality would be able to administer and spend its money on issues of local interest. ${ }^{122}$

Salvemini seriously questioned administrative centralization not only at the level of the central state and the provinces but also at municipal level.123 Indeed, for him, sharing Cattaneo's view, municipal administrations played a key role in Italy and for historical reasons.124 Consequently, municipal life would be in a position to develop only when the central government would suspend all forms of control at that level. ${ }^{125}$ Perfectly autonomous municipalities would be able to associate among themselves in regional federations and in this way autonomously address local affairs without the need for any central intervention. ${ }^{126}$ Municipal autonomy would pave the way for regional government, so that all matters that were not of national interest would be vested in autonomous elective entities ${ }^{127}$ and this would allow Italy to transform from a unitary to a federal state 'conquering all the inestimable benefits of federalism without the need of a true administrative revolution'. ${ }^{128}$ In this regard, Salvemini questioned the authority of prefetti (prefects) in municipalities and provinces, especially their power to approve or annul the decisions of municipal and provincial councils in order to

${ }^{120}$ See G. Salvemini, 'La Questione Meridionale' n 97 above, 19; see also C. Lacaita and F. Sabetti, n 4 above, 30-31.

${ }^{121}$ G. Salvemini, 'La Questione Meridionale e il Federalismo' n 101 above, 85; Id, 'Risposta ad un'inchiesta' n 88 above, 62-63; Id, 'Prefazione' $n 82$ above, XVI.

122 G. Salvemini, 'La Questione Meridionale e il Federalismo' n 101 above, 85.

123 G. Salvemini, 'La Questione di Napoli' n 90 above, 109-110.

124 G. Salvemini, 'L'autonomia comunale' n 57 above, 126.

125 ibid.

126 ibid 127.

127 ibid.

128 ibid. 
affirm the autonomy of these entities. ${ }^{129}$ With the implementation of the 1948 Constitution, Salvemini complained that the role of prefects was preserved with the same functions attributed to them by the fascist and pre-fascist regimes. ${ }^{130}$

In any event, while a convinced advocate of federalism, Salvemini was certainly not so naïve as to believe that a federal solution would work as a magic wand capable of solving all problems. In fact, he acknowledged that, at central level, there would still be conflicts of interest, particularly between the industrial north and the rural south on issues related to customs duties, although these difficulties might emerge in any capitalist state and not just in Italy. ${ }^{131}$ Similarly, Salvemini identified two major risks that might emerge in the case of a federal reform in Italy. First, local administrative malpractices might worsen due to a lack of control and second, this type of surveillance might serve to add central corruption to local corruption ${ }^{132}$ although, for Salvemini, these two risks would be 'less serious in the north and more serious in the south'. ${ }^{133}$

Salvemini also argued that, in spite of a federal system creating a fragmented administrative model, Italians from the north and the south alike would still find in the central (federal) institutions a forum in which to meet, as these bodies represented and protected national unity both internally and externally. However, the conditions that allowed this exchange of ideas would be completely different, as northerners and southerners would not battle between themselves to gain greater financial quotas but would be more willing to co-operate with each other. ${ }^{134}$

As with Cattaneo, Salvemini believed that there was a lack of 'sound current of federal thought' in Italy. The skepticism towards a federal solution for Italy, so widespread in the years preceding unification (an idea that has endured to these days) was due, according to Salvemini, to a certain mistrust 'towards freedom in general'. 135 The lack of experience in local self-government, which several opponents of federalism raised as a flag against a federal reform in Italy, was not so decisive for Salvemini, as he thought that the 'influence of tradition in history is smaller than one might think' and used an analogy to explain this concept more accurately. To purchase an ox, he argued, it is a requirement to know the history of commerce and be the offspring of merchants who bought oxen'. ${ }^{136}$

Salvemini believed that federalism had to be seen and adopted not just as an objective, but also as a method consistent with the ends being pursued. ${ }^{137}$

129 G. Salvemini, 'Federalismo e regionalismo', in Id, Scritti sulla Questione Meridionale n 57 above, 602. Incidentally, prefects were agents of central government (ibid).

130 ibid 605.

${ }^{131}$ G. Salvemini, 'La Questione Meridionale e il Federalismo’ n 101 above, 94.

${ }^{132}$ G. Salvemini, 'Prefazione’ n 82 above, XXXIX.

133 ibid.

134 G. Salvemini, ‘La Questione Meridionale e il Federalismo’ n 101 above, 93.

135 ibid 94.

${ }^{136}$ G. Salvemini, 'La Questione di Napoli’ n 90 above, 121.

137 C. Lacaita and F. Sabetti, $n 4$ above, 36. In fact, Salvemini argued that 'it is not enough 
However, even he eventually had to admit that, at the time of unification, a federal system of public administration would not be viable, because various parts of the country needed bureaucratic protection so as to be moved in the direction of modern civilization. ${ }^{138}$ Unfortunately, the central administration was deaf to these claims and attempted to solve the problems plaguing the south with ad hoc interventions, ${ }^{139}$ a practice that would become very popular also in the decades to come.

In any event, Salvemini was not only critical of the centralized model implemented at unification in 1861 but he also questioned the regional state as embedded in the 1948 Constitution, particularly the creation of regions, as he argued that most of these regions were fictitious and not grounded in Italian history. ${ }^{140} \mathrm{He}$ argued that, after introducing this entity in the Constitution, the founding fathers 'forgot to develop it'. ${ }^{141}$ He believed that the ideal solution would entail the creation of autonomous municipalities and regions as intermediate entities between the comuni and the federal government; yet, the nature and functions of these regions had remained vague and undefined for a long time ${ }^{142}$ and complained that no one had a clear idea of what a 'region' meant; the relationships among regions, central government and local entities were not clearly defined and no financial resources were transferred to them. ${ }^{143}$ He praised the autonomy granted to Valle d'Aosta, which, in his opinion, should have represented the model for all other regions in Italy. ${ }^{144}$

Finally, as with Cattaneo, Salvemini's ideas on federalism were not static, as he evolved from an 'absolute' to a 'moderate' federalism. Salvemini admitted that '(s)everal experiences forced me to pour some water into my federalist wine of

that the federal idea be affirmed in the pages of a book; it shall become part of the political program of democratic parties'. See G. Salvemini, 'La Questione Meridionale e il Federalismo' n 101 above, 106.

${ }^{138}$ C. Lacaita and F. Sabetti, $n 4$ above, 42.

139 Drawing from Giustino Fortunato, Salvemini admitted that all 'special' laws for the Mezzogiorno were nothing but 'sterile deceit' and that special laws for the south should be replaced by an 'Italian campaign' and by a 'general political reform' as any general reform would benefit the south. See G. Salvemini, 'Le leggi speciali', in Id, Scritti sulla Questione Meridionale $\mathrm{n} 57$ above, 589. See also Z. Ciuffoletti, $n 9$ above, 91.

140 G. Salvemini, 'Federalismo, regionalismo e autonomismo' n 116 above, 592. For example, he argued that Emilia is a geographically defined territory, as it is nestled between the Po river, the Adriatic and the Appennini but this territory has never been, in historical terms, an administrative or political administration. See ibid 603. Salvemini criticized the vagueness of the idea of region by questioning the formation of certain regions in the south; he argued that it was nonsense to attach all provinces in Sicily in one single region, as the Eastern provinces did not have any need for that; or the fact that the provinces of Foggia, Lecce and Bari were combined in the same region, Apulia. See G. Salvemini, 'Prefazione' $n 82$ above, XVII.

${ }^{141}$ G. Salvemini, 'Federalismo e regionalismo' n 129 above, 604.

142 G. Salvemini, 'Prefazione' n 82 above, XVI-XVII.

143 G. Salvemini, 'Federalismo, regionalismo e autonomismo' n 129 above, 605.

144 ibid 606 and 608. 
half century ago'.145 Indeed, his 'initial view of federalism derived from his conviction that the political transformation of the liberal-moderate kingdom was a pre-condition to solving both the social and southern question'. ${ }^{146} \mathrm{He}$ also lost faith in the 'political capacity of the southerners' that he had had years before. ${ }^{147}$ With time, however, Salvemini's federalism was influenced by among many others, Giustino Fortunato, ${ }^{148}$ who believed that

'the inferiority of the south vis-à-vis the rest of Italy was linked to its natural, ie physical, geographical and climatic features that would be difficult to change without major state intervention'.149

As a result, federalism per se would not help the cause of the south

'for whatever local autonomy had been granted by the Italian state had paved the way for local élites to gain new powers of domination, or to maintain existing oppression'. 150

\section{Influenced by these ideas, Salvemini}

began to think that federalism, as a system of government and process, would take a long time to realize. It might be best promoted and implemented in different stages experimentally from the grassroots, starting with communal autonomy.151

In this sense, Salvemini was perhaps disillusioned by the fact that the social forces, which were supposed to struggle for more local autonomy, were too weak and thus failed in their attempts ${ }^{152}$ in practice. In time, he acknowledged, as did Giustino Fortunato, that the Mezzogiorno was not capable of taking care of local issues alone and sought help from the north. ${ }^{153}$

145 ibid 612.

146 C. Lacaita and F. Sabetti, n 4 above, 34.

147 G. Salvemini, 'Federalismo e regionalismo' n 129 above, 612.

148 As explained by Lacaita and Sabetti, Giustino Fortunato (1848-1932) was a southern intellectual who extensively published 'analyses of the resources and economic structures of the entire south' and who also criticized 'southern landowners and the educated classes of Naples for their laziness and indifference to local conditions'. See C. Lacaita and F. Sabetti, n 4 above, 34, fn 12.

149 ibid 35.

150 ibid.

151 ibid.

152 ibid 34; G. Salvemini, 'Federalismo e regionalismo' n 129 above, 612, where he admitted that, with time, he had lost his faith in the political capacity of people in the south. Furthermore, Salvemini denounced the 'intellectual, moral and political misery' of southern congressmen, whose main preoccupation was favouritism (see G. Salvemini, 'Prefazione' n 82 above, XXX).

153 See G. Salvemini, 'Federalismo e regionalismo’ n 129 above, 614. 


\section{A Comparison Between Cattaneo's and Salvemini's Federalism}

At the end of this survey of Cattaneo's and Salvemini's federal ideas, what conclusions can we draw? What are the points of convergence and divergence between the two? This comparison can be done having regard both to their federal ideas and their personal lives.

Beginning with their federal ideas, I emphasized how both thinkers were strenuous advocates of a federal solution for Italy, although the rationale behind their federal philosophies was slightly different. In any event, both conceived federalism as a means to elevate the human being, both as an individual and as part of a larger community but in different ways. For Cattaneo, federalism was synonymous with freedom and was thus construed as the way to achieve the utmost liberty (federalism as a 'theory of freedom') both for the individual and in the public sphere. For Salvemini, on the other hand, federalism was primarily the vector for the rural masses in the south to be emancipated and become more active (and consequently less passive) in events directly affecting them and in general, for the emancipation of the south (although this position was later mitigated).

I noted how they were both concerned with the same issue, specifically the north/south socio-economic divide, although their specific points of observation were opposite. Cattaneo understood better the reality of the north, while the Salvemini was the proud expert of the Mezzogiorno. Yet, basically, they reached the same conclusions and both believed that a federal solution for Italy would benefit the whole peninsula and solve many of its problems, including the north/south cleavage. However, Cattaneo's federal vision was perhaps more overarching, in the sense that his focus was not limited to Lombardy or Italy but extended to other European countries and to a 'United States of Europe' project. As Norberto Bobbio argues, Cattaneo was a 'modern and European thinker' although he was working within a 'cultural environment not always open to welcome innovation but rather closed in territorial prejudices'. ${ }^{154}$ Salvemini, on the other hand, took the south of Italy as his point of departure and discussed the benefits that a federal pattern would bring to that specific area of the country. In other words, while, for Cattaneo, federalism was synonymous with freedom and was, more than anything else, an ideal to which all states should aspire, for Salvemini, federalism was the concrete solution, along with universal suffrage, to emancipate the south of Italy. In this sense, it might be argued that, for Salvemini, federalism was much more solidly linked to a specifically southern Italian context, while Cattaneo's federalism was more abstract and idealist.

With specific regard to the Italian unification process, I noted how they both heavily criticized the centralized state model implemented in Italy in 1861, mainly because it put in place a cumbersome and very slow bureaucratic system.

154 N. Bobbio, n 7 above, 6-7. 
Consequently, they both saw in federalism the solution to simplifying bureaucracy. They both acknowledged the importance, historically and politically, of the role played by municipalities (or comuni) in the specifically Italian context. However, while Salvemini spent time discussing how legislative and administrative powers should be divided between the center and the periphery in an ideal Italian federation, 155 Cattaneo failed to devote any specific writing to a federal model for Italy. Rather, his federal ideals were scattered throughout his other political writings. In other words, he invoked federalism without offering a concrete project of federal reform for Italy and for this he was criticized. ${ }^{156}$

While Cattaneo's federal ideas deeply influenced Salvemini, as intellectuals they were profoundly different. Trained as a jurist, the Milanese was an encyclopedic intellectual 157 whose writings touched upon a wide and very diverse array of subject matter, spanning politics to engineering, economics to literature, hydraulics to transportation. Salvemini, conversely, preferred to focus his research interests on politics and history. In any event, they shared the same investigative methodology, as they both believed in the creative force of ideas and the logic of scientific inquiry - that is, the fruit of reason as it proceeds by means of proofs and checks' and both 'loved positive investigations - the empirical analysis of concrete problems'. ${ }^{158}$

Finally, on the more personal side, both Cattaneo and Salvemini lived through very crucial times for Italian institutional history, without being contemporary. Cattaneo experienced in first for himself the decades that transformed Italy from a mere 'geographical expression' into a politically unified national state, while Salvemini lived through the difficult periods of two world wars and the Republican Constitution of 1948. Furthermore, for a several years both intellectuals worked as high school professors and this certainly helped them acquire first-hand experience of the everyday problems of common people and society, abstracted from all privileged perspectives. They both decided at some point in their lives actively to engage at a political level, although they quickly abandoned their political careers, preferring to embrace intellectual, rather than political activism.

In conclusion, this comparative study of Cattaneo's and Salvemini's federal philosophies underscores the extreme modernity of their ideas, as many of the situations that they denounced in their writings (excessive bureaucracy, importance of municipalities in Italy, the socio-economic backwardness of the south, etc) are

155 As noted, the review L'Unità founded and directed by Salvemini contained many writings on federalism.

${ }_{156}$ E.R. Papa, n 23 above, 13, where the author points out that Salvemini himself, among others, used to raise this point.

157 Although not everyone agrees on this idea of Cattaneo as an encyclopaedic thinker. Norberto Bobbio, for instance, argued that he was 'multi-faceted' without being 'encyclopaedic'. See N. Bobbio, $\mathrm{n} 7$ above, 4.

${ }^{158}$ As clarified by C. Lacaita and F. Sabetti, n 4 above, 33. In this sense, also Norberto Bobbio argued that Cattaneo's positivity rested on the fact that he grounded knowledge on experience and that he considered science as a function of his utility. See N. Bobbio, n 7 above, 8. 
still actively debated to this day and are still in need of solution. Re-discovering the work of these two brilliant intellectuals might therefore offer some food for thought even today. 